\title{
Searching the Silence: Finding Black Women's Resistance to Slavery in Antebellum U.S. History
}

Loucynda Jensen

Portland State University

Follow this and additional works at: https://pdxscholar.library.pdx.edu/mcnair Let us know how access to this document benefits you.

\section{Recommended Citation}

Jensen, Loucynda (2006) "Searching the Silence: Finding Black Women's Resistance to Slavery in Antebellum U.S. History," PSU McNair Scholars Online Journal: Vol. 2: Iss. 1, Article 23.

https://doi.org/10.15760/mcnair.2006.135

This open access Article is distributed under the terms of the Creative Commons Attribution-NonCommercialShareAlike 4.0 International License (CC BY-NC-SA 4.0). All documents in PDXScholar should meet accessibility standards. If we can make this document more accessible to you, contact our team. 
Portland State University McNair Research Journal 2006-2008

Searching the Silence: Finding Black Women's Resistance to Slavery in Antebellum U.S. History

by

Loucynda Jensen

Faculty Mentor:

Patricia Schechter

Citation: Jensen, Loucynda. Searching the Silence: Finding Black Women's Resistance to Slavery in Antebellum U.S. History. Portland State University McNair Scholars Online Journal, Vol. 2, 2006-2008: pages [135-161]. 


\section{Searching the Silence: Finding Black Women's Resistance to Slavery in Antebellum U.S. History}

LOUCYNDA JENSEN

PATRICIA SCHECHTER, FACULTY MENTOR

Slave women were everywhere, yet nowhere.

Deborah Gray White (1985) ${ }^{1}$

When Deborah Gray White wrote that "Slave women were everywhere, yet nowhere," she meant that they were ever present in the physical world of antebellum slavery, yet their lives are nearly impossible to find in writing from the time. ${ }^{2}$ Written over twenty years ago, White's concerns remain quite accurate, and our understanding of black female slaves' history has suffered the consequences; remaining partial and incomplete. Adding to the problematic situation of sources, slave women's particular experiences are easily overshadowed by the overwhelming amount of literature on male experience. Nowhere is this clearer than in the realm of resistance to slavery, when masculinist and political modes of rebellion, like flight, revolts, and physical confrontations with masters and overseers fill numerous volumes. ${ }^{3}$ My reading of these literatures suggests that my search for women's resistance to slavery means grappling with silences and gaps, and with attention to gender in the shaping of slave resistance in the antebellum period. Reproductive choices must be analyzed as valid sources of slave rebellion.

\footnotetext{
${ }^{1}$ Deborah Gray White, Ar'n't I a Woman: Female Slaves in the Plantation South (New York: W. W. Norton \& Co., 1985), 23.

${ }^{2}$ Ibid.

${ }^{3}$ For other authors who contributed to the valuable masculinist literature on resistance to slavery in this general time period see John W. Blassingame, The Slave Community: Plantation Life in the Antebellum South (New York: Oxford University Press, 1972); See also Eugene D. Genovese, Roll, Jordan, Roll: the World the Slaves Made (New York: Pantheon Books, 1974); See also Herbert Aptheker, American Negro Slave Revolts (Millwood, N.Y.: Kraus Reprint Co., 1977); See also Kenneth Stampp, The Peculiar Institution: Slavery in the Antebellum South (New York: Knopf, 1956).
} 
This paper will explore the topic of black female resistance to slavery in the antebellum United States with a focus on how female slaves' reproductive decisions, namely abortion and infanticide, can be analyzed as resistance against slaveholders' methods of slave breeding, and therefore against the system of slavery and oppression itself. Within my paper I will appraise how a nuanced definition of resistance can be applied to these gendered methods of opposition, and how other historians before me have chosen to use this term in these instances. I will also investigate how other historians and writers have decided what, or how much, of such information proves that these incidents occurred, and how generalizations about female slaves' reproductive choices have been made. Finally, I will reflect on the varied and slippery nature of the primary evidence that I have found, which includes medical publications, abolitionist journals, WPA slave narratives, newspaper articles, and a plantation journal.

Research and publications searching for an in-depth understanding of the slave experience did not become popular until the 1970s, and even then women were largely absent from the discussion. Thanks to an upsurge in black feminist scholarship on slavery in roughly the past twenty years, research on slaves' experiences began to look at women as an important group to study separately, and once this door was opened generalizations about women's experiences in slavery followed. Before this time it would be safe to say that they were ignored as individuals with their own pasts. Although it would seem that historians of the past twenty years are primarily in agreement on the centrality of female slaves in the antebellum slave system, precise standpoints and methodologies varied among black feminist practitioners in the early years.

Deborah Gray White's work represents an important turning point for the study of slavery, pushed forth by a myriad of black feminist scholars in the academy and outside. Like White, Angela 
Davis published Women, Race, and Class in 1981 and became one of the first authors to focus specifically on the experiences of women. Catching the spirit of this moment in black feminist scholarship, she says that, while scholarly debate on slavery showed signs of "renewed vigor" from the 1970s on, what was "conspicuously absent" was a book dedicated specifically to truth in the lives of slave women. ${ }^{4}$

Davis focuses keenly on the gendered aspects of resistance, pointing out that "women resisted and advocated challenges to slavery at every turn," and their resistance was "often more subtle than revolts, escapes, and sabotage." ${ }^{5}$ On the subject of reproductive choices, Davis seems to tip a Marxist hand in the sense that she is inclined to value women's agency as heroic, highly conscious, and directed at the mode of production. Davis stresses that the system of slavery relied upon "natural reproduction," and she highlights how this practice undermined slaves' roles as mothers, demeaning them to the label of breeders. ${ }^{6}$ This form of oppression, specific to slave women, would create the opportunity for their unique methods of resistance to this reproductive system.

Davis generalizes about female slaves' use of abortion, for example, when she says that "black women have been aborting themselves since the beginning of slavery" due to their refusal "to bring children into a world of interminable forced labor, where chains and floggings and sexual abuse for women were the everyday conditions of life." ${ }^{, 7}$ I was struck by the nature and amount of evidence on which Davis bases her conclusions; in fact she sites only one oft quoted piece of medical evidence when discussing abortion among slave women; a Doctor Pendleton who published

\footnotetext{
${ }^{4}$ Angela Davis, Women, Race, \& Class (New York: Random House, 1981), 3.

${ }^{5}$ Ibid., 21-22.

${ }^{6}$ Ibid., 6-7.

7 Ibid., 204.
} 
his medical opinions on the matter in 1860. Similarly, when discussing infanticide she utilizes the story of Margaret Garner who was once a runaway slave, and a mother who was sent to trial for killing her young daughter instead of allowing her to be taken back to slavery. Due to the availability of sources on this particular case, it is the most oft quoted account from primary evidence. ${ }^{8}$ Davis leaves Margaret Garner to be her reader's emblem and symbol of infanticide, concluding her discussion of infanticide declaring that some women, like Margaret Garner, "were driven to defend their children by their passionate abhorrence of slavery." ${ }^{9}$ Davis' purpose seems to be provocation; to shock her reader out of their assumptions about black women's passivity and silent victimization as slaves. For this reason she uses some powerful rhetorical questions, like: "why were self-imposed abortions and reluctant acts of infanticide such common occurrences during slavery?" She answers by saying that they were "acts of desperation, motivated... by the oppressive conditions of slavery." 10

Sharing in Davis' revisionist goals, Deborah Gray White's 1985 book titled Ar'n't I a Woman is more thoroughly strengthened by its social history perspective and practical archival research methods. White is more cautious about generalizations than Davis, and she flags the dangers of relying on what little primary evidence can be found due to the inability for most black women from the antebellum time period to tell their own stories. ${ }^{11}$ White takes materialist concerns seriously, but she is also aware of the literary and psychological complexities of her evidence; for example, she is aware that, "in short, it is very difficult, if not impossible, to be precise about the effect of any single variable on female slaves," including reproductive choices. ${ }^{12}$ White does seem to

${ }^{8}$ Davis, Women, Race, and Class, 21; See also Steven Weisenburger, Modern Medea: a Family Story of Slavery and Child-Murder from the Old South (New York: Hill and Wang, 1998).

${ }^{9}$ Davis, Women, Race, \& Class, 21 \&29.

${ }^{10}$ Ibid., 205.

${ }_{11}^{11}$ White, Ar'n't I a Woman?, 23-24.

${ }^{12}$ Ibid., 23. 
provide a parallel argument about the ways that female slaves were used as breeders in a system of domestic reproduction prevalent during the time period, and she links this to how slave men and women did not experience slavery in the same way, and therefore sometimes resisted in distinctive ways. $^{13}$

White's methodological caution and lack of a rigid Marxist standpoint results in a divergent conclusion from Davis about how common acts of infanticide and abortion really were. She notes that observers at the time believed that slaves were using abortion to keep from producing viable children for the system, and she provides reasons why slaves would wish to prevent bringing children into such a cruel world; like the desire to deny their white masters "the satisfaction of realizing a profit on the birth of their children" 14 Yet, she further admits that "it is almost impossible to determine whether slave women practiced birth control and abortion. These matters were virtually exclusive to the female world of the quarters, and when they arose they were attended to in secret and were intended to remain secret."15

Correspondingly, White suggests that infanticide was so uncommon of an act among female slaves that she doubts it had any real impact on the rates of slaves' reproductive capabilities for the system of slavery. Acts of infanticide, according to White, represent "atypical behaviors on the part of slave mothers" and she suggests that many accusations of infanticide were actually "smothering" deaths that we might now recognize as Sudden Infant Death Syndrome (SIDS). ${ }^{16}$ Given White's carefully construed conclusions about acts of infanticide and abortion as highly

${ }^{13}$ Ibid., 62.

${ }^{14}$ Ibid., 84-86.

${ }_{15}$ Ibid., 84.

${ }^{16} \underline{\text { Ibid., }}$ 87-89; For more information on the theory that Sudden Infant Death Syndrome (SIDS) was responsible for a majority of "rolling over" or "smothering" deaths wrongfully accused on slave mothers during the history of slavery see Michael P. Johnson, "Smothered Slave Infants: Were Slave Mothers at Fault?,” The Journal of Southern History (1981), 493-520; see also Richard H. Steckel, "Women, Work, and Health under Plantation Slavery in the United States," in More Than Chattel, ed. David Barry Gaspar and Darlene Clark Hine (Bloomington: Indiana University Press, 1996), 43-60; see also Wilma King, "Suffer with Them Till Death: Slave Women and Their Children in Nineteenth-Century America,” in More Than Chattel, 147-168. 
utilized forms of resistance and slave women, I was struck by her extensive use of examples. She not only includes more accounts of either act than Davis, but is also more thorough than any of the other available authors on the topic. She lists 4 cases of infanticide committed by slave mothers where SIDS could not be the cause of death, and two of these cases reflect the fact that the mothers killed their children to save them from suffering the life of a slave. ${ }^{17}$

In 1942, long before many historians were paying attention to slave women in their research, Alice and Raymond Bauer published the article "Day to Day Resistance to Slavery." Although they have some masculinist ideas about what constitutes resistance and who a slave is (male), I am struck by their inclusion of infanticide in their discussion of everyday resistance. The Bauers are not quite certain what to make of infanticide as resistance and a debate on how to interpret these acts does not appear. However, the authors were keenly aware at this early year that this was a valid pattern of resistance that should be studied further, as they claim that "occasionally one runs across a reference to a slave mother killing her child, but statements are almost invariably incomplete" when researching these acts. ${ }^{18}$

A comparison of these sources leads me to ask my own questions. As researchers, how are we to understand the motives and realities behind these kinds of acts? How much evidence is enough to assume high commonality of these acts? Either due to the unavailability of cases, or due to the difficulty in interpreting them, many scholars who have discussed resistance have left infanticide and abortion alone.

Stephanie Camp's 2004 book Closer to Freedom is one example of a source that has contributed a great deal to my understanding of female slave resistance, especially through methods which utilize the physical body. For example, she says that "enslaved people's everyday battles for

${ }_{18}^{17}$ Ibid., 88.

${ }^{18}$ Raymond A. Bauer and Alice H. Bauer, "Day to Day Resistance to Slavery,” The Journal of Negro History (1942), 388-419. 
"regaining" a measure of "control" took place on very "personal" terrain; their bodies." 19 Though she is not concerned with reproductive matters, Camp offers some rich theories about the concept of "everyday resistance," which I feel could help frame the methods of resistance that I am interested in (especially abortion). She shows us how theories of everyday resistance could provide us with a new way of understanding these acts. For example, by studying the "geography of containment" experienced by slaves, Camp illuminates women's methods of resistance because "for bondswomen, even more than for enslaved men, intimate entities, such as the body and the home, were instruments of both domination and resistance." ${ }^{20}$ Theories such as this point to methods of resistance that would seem to corroborate with my evolving sense of female slave resistance through abortion and infanticide.

In 1996 More Than Chattel: Black Women and Slavery in the Americas was published. ${ }^{21}$ Editors David Barry Gaspar and Darlene Clark Hine constructed this compilation of scholarly articles in order to produce a book that would speak to the histories of many different continents of black women. Strikingly, articles on black women in the United States remain speculative about reproductive matters, while those on black women in the Caribbean and Latin America contained explicit information about infanticide and abortion as resistance. Articles including concepts associated with female slave abortion and infanticide cited evidence from doctors, planters, religious leaders, and slave midwives to support their claims. It seems that the amount and breadth of types of evidence for acts of reproductive resistance in these geographical locations is much greater than ours. Two articles in the book deal with black women in the context of childbearing and rearing in the United States. The first, "Women, Work, and Health Under Plantation Slavery in the United

${ }^{19}$ Stephanie M. H. Camp, Closer to Freedom: Enslaved Women and Everyday Resistance in the Plantation South (Chapel Hill: University of North Carolina Press, 2004), 62.

${ }^{20}$ Ibid., 3 \& 6.

${ }^{21}$ David Barry Gaspar \& Darlene Clark Hine, eds., More Than Chattel: Black Women and Slavery in the Americas (Bloomington, Indiana University Press, 1996). 
States," by Richard Steckel, approaches the topic of child-death, but his theme of health leads him only to discuss the "smothering" or "rolling over" deaths of infants that were often wrongfully blamed on carelessness of slave mothers by slaveowners and overseers. All pieces of evidence used to support this section of his article are secondary literature sources in agreement on the subject of infant death in the antebellum south. Steckel does not choose to talk about other kinds of infanticide, or abortion at all for that matter. ${ }^{22}$

Another article in the book, "Suffer With Them Till Death: Slave Women and Their Children in Nineteenth Century America," by Wilma King, does devote some pages to the breeding of slaves and the possibility of infanticide and abortion among those populations, but she falls far short from taking a side on how important these acts could have been if considered as resistance to the system of slavery. Her arguments about breeding and acts of infanticide are understandably ambivalent. For example, in regards to breeding, she says that "American slaveholders viewed motherhood as an asset, and they encouraged reproduction for pecuniary reasons alone." ${ }^{23}$ King insists that slave women and their children were considered chattel instead of persons, and that slave women were, therefore, "unable to control their fertility or to make necessary decisions about their own bodies." 24 Lest the reader think King overly stresses female victimization or lack of power, she also claims that "some women took more drastic steps to undermine reproduction by refusing to conceive children or by aborting them." 25 Her ambivalence points to an on-going dilemma and contradiction in scholarship on this subject: If slave women chose to undermine reproduction through abortion then how are they otherwise unable to control their fertility of make decisions

\footnotetext{
${ }^{22}$ Steckel, "Women, Work, and Health under Plantation Slavery in the United States," 53.

${ }^{23}$ Wilma King, "Suffer with Them Till Death: Slave Women and Their Children in Nineteenth-Century America," 147-8.

${ }^{24}$ Ibid., 148.

${ }_{25}$ Ibid., $159-160$.
} 
about their bodies? In other words, how do we perceive and evaluate choices in an environment of official non-choice, like slavery.

King only appears to flag smothering deaths and their probability to actually have been cases of SIDS, and she discusses these as instances when mothers were accused of infanticide. However, in the end she supposes that it was simply easier for whites to accuse slave women of infanticide than it would have been to understand why the infant mortality rates were so high, and she clarifies that she does not want to deny the documented reports of infanticide that do exist. ${ }^{26}$ In 1999 another important piece of slavery literature was published titled Soul by Soul. In this provocative historical discussion of the largest slave trade in antebellum America, the slave markets of New Orleans, Walter Johnson seems to be challenging his readers to understand the dualistic nature of slave trading. In essence we could say that some saw property for sale and others felt their humanity degraded and sold. While this is an invaluable piece of literature for the history of slavery, Johnson's focus is not solely on reproductive choices. What he does offer to a discussion on reproduction are meticulously researched, countless instances when women's reproductive abilities were on center stage in the markets and auction houses. Descriptions of how slaveholders sometimes made their choices of slave purchase based on the hope of returning a profit from a black slave woman's childbearing abilities. ${ }^{27}$ As Johnson describes the market he says that buyers compared women physically; "they palpated breasts and abdomens, searching for hernias and prolapsed organs and trying to massage bodies into revealing their reproductive history." 28 Johnson argues that one could assume that "buyers were concerned that their female slaves be "breeders.", ${ }^{29}$

\footnotetext{
${ }^{26}$ Ibid., 160.

${ }^{27}$ Walter Johnson, Soul by Soul: Life Inside the Antebellum Slave Market (Cambridge: Harvard University Press, 1999), 83-144.

${ }^{28}$ Ibid., 143-4.

29 Ibid., 144.
} 
In affirming that slave women's reproductive choices should be defined as resistance an explanation of their place within the system of slavery is advantageous. Black slave women in the antebellum United States were very highly valued for their reproductive abilities. White purports that "once slaveholders realized that the reproductive function of the female slave could yield a profit, the manipulation of procreative sexual relations became an integral part of the sexual exploitation of female slaves." ${ }^{30}$ In other words, their purpose was largely to accommodate masters by continuing to contribute to the very system that oppressed them.

In Charles Parsons's journal published in 1855 as Inside View of Slavery; or, A Tour Among the Planters, Parsons frankly writes, "The term slave has a definite meaning. It signifies, not a person, but a thing, a chattel..." 31 For everyone involved in the system of slavery this meant that "a slave child was property; its birth added to a slaveholder's coffers regardless of the conditions under which it was conceived." 32 Due to the desire to continue reproduction of their chattel, masters often aimed to breed their slaves as often as possible, therefore, yielding the most profit (or capitol) as was possible over time.

It is well documented that slave women for sale often went listed with important information regarding their breeding or reproductive quality. Many times slaves were even explicitly listed as breeders if they were young and able to bear many children. ${ }^{33}$ Furthermore, much public attention was given to black slave women's reproductive abilities. For example, White says that "major periodicals carried articles detailing optimal conditions under which bonded women were

\footnotetext{
${ }^{30}$ White, Ar'n't I a Woman?, 68.

${ }^{31}$ Charles Parsons, An Inside View of Slavery: or A Tour Among the Planters (Boston: John P. Jewett and Co., 1855), 54.

${ }^{32}$ King, “Suffer with Them Till Death,” 159.

${ }^{33}$ Erlene Stetson, "Studying Slavery: Some Literary and Pedagogical Considerations on the Black Female Slave," in All the Women Are White, All the Blacks are Men, But Some of Us Are Brave, eds. Gloria T. Hull, Patricia Bell Scott, and Barbara Smith (New York: The Feminist Press, 1982), 74.
} 
known to reproduce, and the merits of a particular "breeder" were often the topic of parlor or dinner table conversations." 34

One ex-slave named Hannah Jones who contributed to the WPA narratives specifically remembered how the system of breeding looked where she grew up a slave. She described how "the niggers had three or four wifes before de war, as many as dey could bear chillun by." ${ }^{35}$ She continues this theme of reproduction as key when she says that the doctor told her grandmother's master that "she's stone blind, but she can have chillun right on," and her master "kept her for dat and she bore twelve more head of chillun after dat." 36 Jones also states that "when dey want to raise certain kind a breed of chillun or certain color, dey just mixed us up to suit dat taste, and tell de nigger dis is your wide of dis is your husband and dey take each other... and raise big families to de white folks liking." 37 This situation would clearly suggest that a breeding system was in place on this plantation.

Another remembrance of breeding practices is illuminated in the 1969 compilation of pieces of WPA slave narratives titled Lay My Burden Down, and it has circulated through many literatures since then. Ex-slave Rose Williams explains how she was purchased under the description of a "portly, strong wench," who would "make the good breeder." ${ }^{38}$ On the new plantation she was sent at age sixteen to live with a slave man named Rufus who she did not like. When she asked her mistress why she was to live with him she was told, "you am the portly gal, and Rufus am the portly man. The massa wants you-uns for to bring forth portly children." After continuing refusal of the situation, her master told Williams, “woman, I’s pay big money for you, and I’s done that for the cause I wants you to raise me childrens. I's put you with Rufus for that purpose. Now, if you doesn't

\footnotetext{
${ }^{34}$ White, Ar'n't I a Woman, 31.

${ }^{35}$ WPA Slave Narrative Project, “Hannah Jones,” Missouri Narratives, Vol. 10 (1936-1938), 214.

${ }^{36}$ Ibid., 215.

${ }_{37}$ Ibid., 216.

38 B. A. Botkin, ed., Lay My Burden Down: a Folk History of Slavery (Chicago: University of Chicago, 1945), 160.
} 
want whipping at the stake, you do what I wants." 39 In the end Williams did oblige her master and reproduce with Rufus because she understood it to be her job without choice.

It has been commonly agreed upon in slavery literature that slaves were indeed viewed as chattel, and that breeding was a fairly common method of increasing or maintaining a slaveholder's capital. The fact that black slave women were labeled as breeders makes their reproductive choices highly political and important. As Davis argued; "Since slave women were classified as "breeders" as opposed to "mothers," their infant children could be sold away from them like calves from cows." ${ }^{\prime 0}$ The continuation of a degrading breeding system within the already cruel and oppressive system of slavery came with repercussions. As Camp has emphasized, "those who encounter oppression through the body, the body becomes an important site not only of suffering but also ... resistance." ${ }^{41}$ Black women living as southern slaves have encountered great oppression, exploitation, and violence on their bodies. Upon reviewing this material, it seems to me important to consider how these slave women sometimes chose abortion, which is an obvious act of resistance acted out in their physical bodies, to challenge the demands made on them by the patriarchal white society, and system of slavery, that they were forced to live in. Acts of infanticide involved the bodies of their children, who were in the same dangerous positions as they had often been, and in this way applies to the same theory. As Camp affirms: "For bondswomen, even more than for enslaves men, intimate entities, such as the body and the home [and the family], were instruments of both domination and resistance." 42

\footnotetext{
${ }^{39}$ Botkin, Lay My Burden Down, 161-2.

${ }^{40}$ Davis, Women, Race, \& Class, 7.

${ }^{41}$ Camp, Enslaved Women and Everyday Resistance in the Plantation South, 62.

${ }^{42}$ Camp, Enslaved Women and Everyday Resistance in the Plantation South, 4.
} 
Due to slave women's roles as reproducers of property and capital in the system of slavery, any successful efforts that they made to curb reproduction meant a loss of capital for their master, and a loss of population for the system itself. In this most basic sense, any reproductive choices that slave women made could affect their system of oppression and, therefore, should rightly be deemed as resistance to slavery. Both abortion and infanticide were defiant acts given what we know about the procreative expectations placed on slave women in the antebellum U.S. south. Whether or not this reproductive resistance to slavery affected the system on a massive scale is not relevant in the considerations of qualifying it as resistance. Defense of their children's lives through claiming and then ending that life is a valid act of resistance.

Camp validates everyday resistance in her research and claims that these everyday acts of resistance should not be devalued or seen as trivial acts. She defines everyday forms of resistance as "hidden or indirect expressions of dissent, quiet ways of reclaiming a measure of control over goods, time, or parts of one's life," and asserts that they could indeed affect the system of slavery. ${ }^{43}$ If acts that could be seen as everyday can be qualified as resistance, who is qualified to deem insubordinate acts of reproductive choice unfitting for this designation?

\section{$* * *$}

Historian Herbert Aptheker seemed to take on this task when he published an article titled “American Negro Slave Revolts" in 1937. Aptheker argues that "the persistent and desperate struggles of the American Negro against slavery took eight forms, none of which have received anything like the treatment they deserve: (1) The purchase of freedom; (2) strikes; (3) sabotage; (4) suicide and self-mutilation; (5) flight...; (6) enlistment in federal forces...; (7) anti-slavery

\footnotetext{
${ }^{43}$ Camp, Enslaved Women and Everyday Resistance in the Plantation South, 2.
} 
agitation...; (8) revolts." These acts are not only masculinist in nature, but the listing of them as the eight forms of resistance completely ignores methods of female resistance to slavery; namely resistance through reproductive choice. While I was not surprised that literature from 1937 would have ignored women's struggles to resist, I found that this list could still be useful in my own creation of a definition of resistance. Aptheker has given us a model of what male centered resistance looks like, and we can utilize this in our understanding of what constitutes female centered resistance.

While some would argue that infanticide and abortion could be valued as expressions of oppression; in other words, that these acts were carried out only in response to the oppressive living conditions of the system of slavery itself; I disagree. If slave mothers made a reproductive choice based on their own motives and experiences, and unintentionally, negatively affected the reproductive system of breeding meant to continue the oppressive system, then I judge this still resistance. A comparison can easily be taken from one of Aptheker's modes of resistance. The first method that is listed is purchase of freedom. Attempting to empathize with a slave's position as a piece of property within the system of slavery, would obtaining their freedom through purchase be a goal set to intentionally destruct the system? Or is it much more likely that a slave would choose to purchase their freedom explicitly for the betterment of their own lives? I would argue that it would be the latter motivation. Further, if a slave is purchasing their freedom, as opposed to becoming a fugitive in the hopes of stealing it, is this not also in a sense complicit with the rules that the system has mandated? This same model can be used to argue that infanticide and abortion were indeed valid forms of resistance to the oppressive system of slavery under which black slave women survived. If we are to argue that slave women's reproductive choices, here discussed through abortion and infanticide, were not resistance, than we would be forced to re-evaluate all accepted methods of resistance to slavery. 
Assuming that infanticide or abortion must be placed in the sphere of resistance should not mean a dismissal of slave women's great maternal love for their children. Acts of infanticide and abortion, or any other reproductive choices, do not necessitate a demeaning of slave women's humanity in terms of their children and families. The truism that creates a space where slave women existed as breeders, mothers, and sometimes destroyers, is that we can not use either/or questions when defining slaves' experiences. These women were not simply mothers or destroyers, just as they were not breeders or mothers. Camp persuasively argues that "enslaved people were many things at once," so the attempted use of dichotomous choices when summing up their existence is irrelevant. "For instance," Camp adds "the ways in which they were both agents and subjects, persons and property, and people who resisted and who accommodated- sometimes in one and the same act." ${ }^{44}$ It is too large of a simplification then to say that slave women who committed acts of infanticide had no effect on the system just because "the cases represent atypical behavior on the part of slave mothers," as White has said. ${ }^{45}$

While "American slaveholders viewed motherhood as an asset, and they encouraged reproduction for pecuniary reasons alone," slave mothers were not unaffectionate with their offspring. ${ }^{46}$ They loved their children and attempted to shield them from the cruelty of the system of slavery however they thought possible. White's description of slave mother's acts of infanticide as atypical was related to the ingrained love that they actually had for their children. ${ }^{47}$ The removal of their child (or children) from the violent and oppressive life that they lived must sometimes have

\footnotetext{
${ }^{44}$ Camp, Enslaved Women and Everyday Resistance in the Plantation South, 1.

${ }^{45}$ White, Ar'n't I a Woman?, 87-8.

${ }^{46}$ Steckel, "Women, Work, and Health under Plantation Slavery in the United States," 147.

${ }^{47}$ White, Ar'n't I a Woman?, 88.
} 
seemed the only way to protect them. Also, Wilma King pointed out that "many slaves came to believe that their distress would end, if not in their present life, then certainly in the afterlife." 48 Many slave mothers may have supposed that they were not only defending their children from the cruel world of slavery, but that they were in essence sending them to a harmonious afterlife.

The question of commonality of acts of infanticide and abortion is a slippery one. Reviewing the secondary source literature, I initially assumed that primary sources containing information on specific acts of this form of resistance would be very minimal. After all, White had provided the most samples in her study from 1985, and she listed only four non-smothering deaths in cases of infanticide. For the purpose of my study I immediately dismissed acts of infanticide that could be even remotely linked to the modern assumptions regarding Sudden Infant Death Syndrome (SIDS). Cases of abortion in White's book were even fewer, with one actual account of abortion and two doctor's reports stating that they believed it did occur among slave women. The other pieces of information that she provided were focused on the probability that some kind of contraceptive or abortive was utilized by slave women to keep them from reproducing when forcibly paired with partners who they did not like under the system of breeding that slaveholders used. ${ }^{49}$ Also, I was most interested in those pieces of evidence that I could locate and analyze myself, and some of the acts that she notes were out of my reach. Furthermore, many of the other secondary sources that provided information on these forms of black female slave resistance highlighted the same one account of infanticide repeatedly, making it seem the only piece of evidence for infanticide that I

\footnotetext{
${ }^{48}$ King, "Suffer with Them Till Death,” 156.

${ }^{49}$ White, Ar'n't I a Woman?, 84-89.
} 
would be able to track down; the case of Margaret Garner, previously mentioned. Cases of abortion were all but invisible.

However bleak this evidentiary situation may have initially looked, I soon realized that current historians are at a great advantage in their ability to locate primary sources in a new way; online. After following the faint trails that previous researchers had left for me, I was able to locate at least twelve separate acts of infanticide that have been noted, and six of those were acts that I could analyze myself in primary source materials. It is noteworthy that five of the six accounts that I was able to read in primary source material specifically say that the mother admitted to killing their children in order to save them from the brutality of slavery. In other words, they committed acts of infanticide, as I had believed, out of love and hope for defense of their children.

I was also able to locate seven pieces of evidence regarding the use of abortion among female slaves. Although these are more ambiguous in relation to cause, I would have expected this considering the complex realities that birthing in the nineteenth century encompassed. Therefore, I will not be attempting to claim that abortion was an act of defense for their unborn children, although I personally subscribe to this theory. I would speculate that more often than not these women too were interested in defending their offspring from a life that they found nearly unbearable. Of the seven cases that I located in regards to abortion, four of these are primary source materials, and three of those appear to be strong evidence for the existence of abortion among female slave populations (one of these three being a medical source record listing a plantation doctor's opinion on the matter). It would seem that in order to draw conclusions from the evidence that I located a detailed account of each piece would be advantageous. I will begin with acts of infanticide that I was able to corroborate through primary sources. 
By far the most utilized story of female slave infanticide is that of Margaret Garner. ${ }^{50}$

Although the high frequency of retelling of this story does result in some minor variations in the details, the account remains provable through myriad primary sources from the time. The story of this one slave mother and her rebellious act of infanticide seems to have become national news, as newspaper articles from New York, Kentucky, and Cincinnati (at least) can be located for reporting of it. In the book Reminiscences of Levi Coffin, which was originally published in 1876, the author admits that he himself was to be involved in the safe conduction of Garner's escape party to a connection in the Underground Railroad where they were to be led north to freedom. ${ }^{51}$ Coffin claims, "Perhaps no case that came under my notice, while engaged in aiding fugitive slaves, attracted more attention and aroused deeper interest and sympathy than the case of Margaret Garner, the slave mother, who killed her child rather than see it taken back to slavery." ${ }^{2}$

From the astounding amount of evidence available on the Margaret Garner case, her story can be accounted with some accuracy. She was a young plantation slave woman who, in January 1856, attempted escape. An atypically large group of runaway slaves were involved and banded together to leave their plantations in border counties of Kentucky in hopes of connecting with the Underground Railroad and finding freedom in the North. Among the group were Margaret Garner, her husband Simon, Jr., their four children (two boys and two small girls), Simon Jr.'s parents Simon and Mary Garner, and nine other slaves from neighboring plantations. Once the slaves had crossed the frozen Ohio River they made their way to Cincinnati. There the groups separated and the

\footnotetext{
${ }^{50}$ For the Margaret Garner story many secondary, and some primary sources can be utilized. See Levi Coffin, Reminiscences of Levi Coffin (Cincinnati: The Robert Clarke Co., 1898) [orig. published 1876], 557-567; see also Julius Yanuck, “The Garner Fugitive Slave Case,” The Mississippi Valley Historical Review (June 1953), 47-66; see also Weisenburger, Modern Medea; see also Davis, Women, Race, and Class, 21-29; see also Bauer, "Day to Day Resistance to Slavery,” 416; see also J. Winston Coleman, Jr., Slavery Times in Kentucky (Chapel Hill: The University of North Carolina Press, 1940), 208-9.

${ }^{51}$ Coffin, Reminiscences, 559.

${ }^{52}$ Ibid., 557.
} 
Garners sought temporary refuge in the home of Elijah Kite, who was to aid them in their escape with direction from Levi Coffin. Unfortunately, the Garner family had been spotted and soon the slaveowners themselves arrived with marshals in tow, prepared to capture the fugitives. Sensing that hope of freedom was lost, Margaret Garner resolved not to allow her children to be captured alive. She found a large knife and cut the throat of her three-year-old daughter Mary. She also attempted to kill her other children, stabbing both of the boys, and once the knife was taken away, hitting her youngest baby, Priscilla, in the face with a shovel. Her attempts to kill all of her children were not successful, and all but Mary survived. The entire family was arrested and a court proceeding followed, in which she was accused of murder, but not tried before her return to her owner. ${ }^{53}$

Margaret Garner's motivations for killing her children appeared obvious to news reporters who recaptured the dramatic events in detail for their readers in the days that followed. The first published news regarding the event ran on January 29, 1856 in the Cincinnati Gazette, and was subtitled "A Slave Mother Murders her Child rather than see it Returned to Slavery." ${ }^{54}$ This same day a similar article would run in the Cincinnati Enquirer with many of the same details made available in the Gazette. Later, during the inquest that ensued, Margaret's mother-in-law Mary Garner would testify that Margaret had told her, "Mother, I will kill my children before they shall be taken back, every one of them." ${ }^{55}$ Mary Kite, resident of the house and witness to the act of infanticide,

\footnotetext{
${ }^{53}$ This account of details regarding the Margaret Garner act is summarized from multiple secondary and primary sources. See Coffin, Reminiscences, 557-567; see also Yanuck, "The Garner Fugitive Slave Case," 47-66; see also Weisenburger, Modern Medea; see also Davis, Women, Race, and Class, 21-29; see also Bauers, "Day to Day Resistance to Slavery,” 416; see also Coleman, Jr., Slavery Times in Kentucky, 208-9.

${ }^{54}$ The Cincinnati Gazette, "Arrest of Fugitive Slaves: A Slave Mother Murders her Child rather than see it Returned to Slavery,” January 29, 1856, as published in Weisenburger, Modern Medea, 87.

${ }^{55}$ New York Times, “The Slave Tragedy in Cincinnati,” February 2, 1856.
} 
corroborates this motive by testifying that Margaret also told her that "she would rather kill them all than have them taken back over the river." 56

Her sensationalist story has continued to emanate throughout the last century and a half as the example of female slave infanticide. She continues to play the role of emblem and symbol in this space in history. Due to the striking detail that has been accounted in news sources from the time this story has remained in the minds of historians and writers who seek a graphic story of infanticide for myriad purposes. Garner's story has been memorialized in books like Toni Morrison's Beloved published in 1987 (and later turned into a movie) and Steven Weisenburger's 1998 publication titled Modern Medea: a Family Story of Slavery and Child-Murder from the Old South. It has also been reproduced in multiple plays and research papers. ${ }^{57}$ When writing his book Modern Medea, Weisenburger raises questions about how we should interpret Garner's actions. He rhetorically asks if her actions were rebellious, and answers that they certainly were, and should be recognized as such because "as for infanticide, what had Margaret Garner done? Destroyed her mater's property..."58 In 1867 Garner's story also inspired a painting done by Thomas Satterwhite Noble called "Modern Medea.",59

Although Margaret Garner's story is the most sensationalized, her continued role as our modern symbol of female slave infanticide should not overshadow those stories of other women who used this same method of resistance. Records of their resistance are less extensive, and therefore, details surrounding their acts are less understood. After all, we can only recreate history from the evidence that we have.

\footnotetext{
56 Ibid.

57 Cameron McWhirter, Cincinnati Enquirer, “A Remnant of Slavery’s Horror,” October 2, 1998; see also Weisenburger, Modern Medea.

${ }^{58}$ Weisenburger, Modern Medea, 77.

${ }^{59}$ McWhirter, Cameron, Cincinnati Enquirer, “A Remnant of Slavery’s Horror.”
} 
The second piece of evidence of infanticide related to my study comes from a WPA narrative of ex-slave Lou Smith. In her narrative Smith tells us of a woman who was owned by a cruel neighboring plantation master, and who ultimately found that the only way that she could resist the impending placement of her baby in the slave market was to take its life. Smith says that this "woman was the mother of several chillun and when her babies would get about a year or two of age he'd [master] sell them and it would break her heart. She never got to keep them. When her fourth baby was born and was about two months old she just studied all the time about how she would have to give it up and one day she said, "I just decided I'm not going to let old Master sell this baby; he just ain't going to do it." She got up and give it something out of a bottle and purty soon it was dead. 'Course didn't nobody tell on her or he'd of beat her nearly to death." ${ }^{, 0}$ The mother in this case seems to have known that she acted defiantly by making her own decision about the fate of her baby. Smith evidently knew it was rebellious and resistant since she adds that it was understood by the other slaves that telling on her would result in severe punishment for her act.

In 1846 ex-slave Lewis Garrard Clarke published his own narrative in the lengthy form of a book called Narratives of the Sufferings of Lewis and Milton Clarke. When relating his answer to the question, "Have you ever known a slave mother to kill her own children?" Clarke gives us two accounts of infanticide that he was aware of. The first is described as follows: "There was a slave mother near where I lived, who took her child into the cellar and killed it. She did it to prevent being separated from her child." He follows this infanticide account with a second: "Another slave mother too her three children and threw them into a well, and then jumped in with them, and they were all

\footnotetext{
${ }^{60}$ WPA Slave Narrative Project, “Lou Smith,” Oklahoma Narratives, Vol. 13 (Interviewed August 12, 1937), 302; See also Dorothy Sterling, ed., We Are Your Sisters: Black Women in the Nineteenth Century (New York: W. W. Norton \& Co., 1984), 57-8.
} 
drowned." ${ }^{\prime 11}$ Not only does Clarke provide us with two accounts of infanticide committed by slave mothers, but he points out that the first mother had done so to keep from being separated from her child. It is likely that, similar to the preceding story provided by Lou Smith, this mother was afraid of the separation of her child and the deliverance of it into the slave market, where any number of fates could befall it. Infanticide was her answer to the question of, how to choose her child's fate herself, and how to defend her offspring. Clarke also comments on the acts of infanticide himself. He says, "Other instances I have frequently heard of," and "At the death of many and many a slave child I have seen the two feelings struggling in the bosom of a mother--joy that it was beyond the reach of the slave monsters, and the natural grief of a mother over her child. In the presence of the master, grief seems to predominate; when away from them, they rejoice that there is one whom the slavedriver will never torment." ${ }^{62}$ What Clarke is pointing to is key. As I have previously mentioned, these mothers did not kill their children due to lack of maternal love, but instead they did it so that their child could be "one whom the slave-drive will never torment." They chose to live with grief rather than allow their children to live with misery.

The next piece of evidence comes from Frederick Law Olmsted's published journal $a$ Journey in the Seaboard Slave States, from 1856. As Olmsted traveled through Alabama he stated that, "A negress was hung this year in Alabama, for the murder of her child. At her trial, she confessed her guilt. She said her owner was the father of the child, and that her mistress knew it, and treated it

\footnotetext{
${ }^{61}$ Lewis Garrard Clarke, Narratives of the Sufferings of Lewis and Milton Clarke, Sons of a Soldier of the Revolution, During a Captivity of More Than Twenty Years Among the Slaveholders of Kentucky, One of the So Called Christian States of North America, Documenting the American South (University Library: The University of North Carolina Chapel Hill, 1999 [Originally published in 1846], http://docsouth.unc.edu/clarke/clarke.html, 76; For the first account See also Johnson, Soul By Soul, 34.

${ }^{62}$ Clarke, Narratives of the Sufferings of Lewis and Milton Clarke, 76; for the first account See also Johnson, Soul By Soul, 34.
} 
so cruelly in consequence, that she had killed it to save it from further suffering." ${ }^{\prime 3}$ Like the mother discussed by Clarke, this mother chose her own grief over her child's, as slave women were often choosing from among a range of sufferings; a spectrum of griefs.

The sixth, and final, piece of evidence that I was able to corroborate through location of primary source materials is the story of a slave named Sylva, who is said to have taken the lives of, not one, but all thirteen of her children. I was struck by the substantial number of children listed, but this was a normal number of pregnancies for a healthy rural woman in antebellum America, and many female slaves were expected to reproduce many children (as previously noted), so she could have just been resolute to terminate each of her children's lives as she claimed. In Parsons's 1855 publication of An Inside View of Slavery, he relates a story told to him by the mistress of the plantation on which Sylva lives. He was told that "Sylva says... that she has been the mother of thirteen children, every one of whom she destroyed with her own hands, in their infancy, rather than have them suffer in slavery!" ${ }^{\prime 4}$ While Parsons does not elaborate on this story, or his own thoughts of it, we do learn of the acts of infanticide while hearing about the abuses that Sylva has suffered at the hands of her master. This left me to ponder whether Parsons does not discuss the infanticide because he understands the mother's motivation, to save her children from such cruel treatment, or if the author leaves this story with an exclamation point due to the anti-slavery context/audience of his time, letting the episode speak for itself. ${ }^{65}$

Though I have six other cited acts of infanticide, they are completely based on secondary source evidence, and therefore the causes of the acts are widely unknown. For this reason I will conclude sorting of evidence regarding acts of infanticide here and move on to those 2 acts of

\footnotetext{
${ }^{63}$ Olmsted, Frederick Law, a Journey in the Seaboard Slave States: With Remarks on Their Economy, Documenting the American South (University Library: The University of North Carolina Chapel Hill, 2001 [Originally published in 1856], http://docsouth.unc.edu/olmsted/olmstead.html, 601-2; See also White, Ar'n't I a Woman?, 88.

${ }^{64}$ Parson, An Inside View of Slavery, 212; See also Bauer, “Day to Day Resistance to Slavery,”417.

${ }^{65}$ Parson, An Inside View of Slavery, 212.
} 
abortion, and 1 piece of medical evidence, all from primary source materials, which can provide some evidence on the use of such a method of resistance by slave women.

The first of these pieces of evidence comes from a plantation journal, which would have likely been updated by overseers and masters to keep records on slaves' condition, work, whereabouts, and issues. Although the Ferry Hill Plantation Journal was written between January 4, 1838 and January 15, 1839 by John Blackford, it was not published until 1961 with editing by Fletcher M. Green. In the journal we read that,” Daph miscarryed two children this morning. sent for Mrs. Fry who came, she is quite ill. the two children which Daph miscarryed she is supposed to have gone with 4 months Both female. It was an hour or upwards between their birth. It is thought she took medicine to produce their destruction." ${ }^{\prime 66}$

The second piece of evidence comes in the form of a medical journal article from the antebellum South. In 1860 Dr. John H. Morgan not only published his article "An Essay on the Causes of the Production of Abortion among our Negro Population" in the Nashville Journal of Medicine and Surgery, but he also read it to the Rutherford County Medical Society that same year. ${ }^{67}$ Within this piece of evidence we can not only locate a professional medical opinion that abortion was indeed being utilized by slave women, but Morgan also notes two actual acts of abortion that seem authentic. We will start by analyzing his expert opinion on the matter, and then move on to the abortive acts.

Dr. Morgan is writing on abortion among slaves, but he first admits that he believes the most common causes of sterility and abortion to be hard labor and mistreatment put on slave women while pregnant. He adds that sometimes slave women are "willing and even anxious to avail

${ }^{66}$ Fletcher M. Green, Ferry Hill Plantation Journal: January 4, 1838- January 15, 1839, Documenting the American South (University Library: The University of North Carolina Chapel Hill, 1998 [Originally published in 1961]), http://docsouth.unc.edu/blackford/blackford.html, 25-6; See also White, Ar'n’t I a Woman, 84.

${ }^{67}$ John H. Morgan, M.D., "An Essay on the Causes of the Production of Abortion among our Negro Population,” Nashville Journal of Medicine and Surgery (August 1860). 
themselves of an opportunity to effect an abortion or to derange menstruation." ${ }^{68}$ He continues by adding that "the remedies mostly used by the negroes to procure abortion are the infusion or decoction of tansy, rue, roots and seed of the cotton plant, pennyroyal, cedar berries and camphor, either in gum or spirits," and some of these items are readily available to them in local gardens. ${ }^{69}$ Morgan also declares that he has been questioned by blacks if camphor would make a woman miscarry, and he attributes the length of the list of abortives being attempted to the ambiguity revolving around which medicines are the most effective. ${ }^{70}$

Although Morgan writes that his medical opinion is that "it is a very rare thing for negroes to resort to mechanical means to effect an abortion," he relates, in his essay, a contradictory and graphic act to this. ${ }^{71}$ Morgan writes that another doctor had informed him of one specific case where a black slave woman was examined and was found to have deliberately procured an abortion by using mechanical means, and she was successful. ${ }^{72}$

The other case that Morgan includes in his essay is of most interest to me because confession was attained from the slaves that were thought to be using abortives. Dr. Morgan was informed by a Dr. Smith that there was a family of slave women who were suspected of inducing abortions for a multi-generational time span. Even when the master had sold the suspect slaves and replaced them with women "who were in the habit of having children every eighteen months or two years," he noticed that "every conception was aborted by the fourth month. The negroes finally confessed that they did take medicine for this purpose, and showed their master the weed which was their favorite remedy."73

\footnotetext{
${ }^{68}$ Morgan, “An Essay on the Causes of the Production of Abortion among our Negro Population,” 117.

${ }^{69}$ Ibid., 117-8.

${ }^{70}$ Ibid., 119.

${ }^{71}$ Ibid., 120.

72 Ibid.

${ }^{73}$ Ibid., 122.
} 
While Dr. Morgan does support the theory that slave women were known to be using abortion as a reproductive choice, he does not conclude with any opinions on the motivations or on this as a method of resistance as his essay is intended for a medical audience only.

Analyzing this evidence, both in volume and in credibility, I would conclude three things. First, sources are out there, and they are becoming more available. It is time for someone to research these acts further in an endeavor to accurately recreate this part of female slaves' history as much as is possible. Second, abortion and infanticide did occur in the antebellum slave south and it can, therefore, be validly claimed as female resistance to slavery due to the agency that was required from black slave women to commit these acts, and the rebellious nature at the heart of them. Third, assumptions of commonality regarding infanticide and abortion will have to wait for future study. There is simply not enough evidence to label these acts common. Besides, one must wonder; common compared to what? Also, it is not necessary to deem infanticide and abortion common in order to validate these methods of resistance among slave women. Previous scholars have possibly used the ambiguous evidence to prove a point when it was necessary for women's history that it be done. They understandably desired to create a space where slave women would be valued as contributors to resistance of the system of slavery.

Female slaves' reproductive decisions, namely abortion and infanticide, are just one space where these women contributed to resistance against the system that oppressed them. They challenged this system in myriad other ways that have not been explored in enough detail. Female slave history has suffered from the lack of sources that are available to tell their story; to share their voices; but in searching the silences and gaps I hope that their stories are not lost. Our modern understanding of resistance includes things like everyday resistance and, therefore, it should become more inclusive to female resistance to slavery as well. If we are to accept masculinist methods of resistance as resistance, then we must be prepared to welcome other gendered forms of resistance 
utilized by female slaves. Women undoubtedly found their own methods of resistance where it seemed there may have been none. They were not silent, as it seems in a majority of the sources, and as this becomes more apparent, there are many of us who demand to find their voices. 